\title{
'Digital What?': Electronic Money and the Future of Australia's Financial System
}

\author{
Stephen Kirchner
}

'Digital what?': Alan Blinder, US Federal Reserve Board Vice-Chairman, asked whether the Fed is studying regulatory issues surrounding digital cash. (Cited in Holland \& Cortese, 1995:46)

7 HE Wallis inquiry into the Australian financial system has been prompted by significant changes in the financial sector since the Campbell and Martin

1 Reports were handed down over a decade ago. Not the least of these changes have been rapid innovations in banking and payments technologies. The inquiry reflects widespread recognition that the existing regulatory framework for the financial system is increasingly inappropriate for the many tasks it is expected to perform.

At the same time, however, there is a risk that the new inquiry will underestimate the extent of the challenge being posed to regulators by new developments in electronic payments and settlement systems. These developments, which have the potential to radically transform the nature of the monetary system and its relationship to the economy as a whole, are to be welcomed. However, the implications for the government and its finances are far less favourable: regulators need to prepare themselves for a significant diminution in their influence over the economy.

\section{The Growth of Electronic Money and Payments Systems}

Considerable attention has been paid in recent years to the potential for electronic payments systems, especially electronic money, to revolutionise the way in which we conduct routine financial transactions. Smart-card technology increasingly looks set to replace cash as the preferred medium of exchange. Electronic money will allow us to buy and sell goods and services through the information superhighway quickly and cheaply, leading to significant reductions in transaction costs across the world economy. This in itself is a significant development, given the important role of transaction costs in determining the nature and extent of an economy's production possibilities (North, 1990).

Major banks and credit card companies, such as Citicorp, Visa and MasterCard, are forming alliances with software giants, such as Microsoft, and telecommunications companies such as AT\&T, and investing enormous sums into the development of electronic money. A number of trials, such as the European Union's CAFE project, are already under way. According to one estimate by Booz, Allen and Hamilton, up to 20 per cent of household expenditures will be made with e- 
money within 10 years (Holland \& Cortese, 1995:37-8). The Mondex electronic purse system is forecast to account for about 60 per cent of the volume of cash transactions worldwide within 15 years (Stuber, 1996:14). Competition in the market for banking, payments and settlements services is about to go global, with international non-bank information technology companies set to replace national bricksand-mortar branch banking as the main suppliers of these services.

The main obstacle at present to the widespread use of electronic money are network externalities and some outstanding security concerns. Network externalities arise from the 'critical mass' needed to get a new payments system off the ground, given that few people will have an incentive to participate in a payments system that is not already widely used by others. However, with the involvement of some major corporations and governments in the development of electronic payments systems, these network externalities are unlikely to constitute a significant long-term obstacle to their adoption.

Security concerns are also being satisfactorily addressed. Recent advances in public key cryptography on the part of firms such as DigiCash offer users of emoney levels of security comparable to, if not better than, that currently used to prevent the unauthorised use of nuclear weapons and to secure large-value wire transfers (Chaum, 1995). These high levels of security also have the added advantage of offering users of e-money very high levels of privacy. Users of e-money can make payments without identifying themselves, since the money can authenticate itself without leaving the paper trail that is characteristic of existing payments systems.

\section{Implications for Monetary and Fiscal Policy}

E-money has two further, potentially even more significant, features, whose implications the authorities are reluctant to face. The first is that e-money can be backed by any valuable asset or commodity: it need not be anchored on a national currency. Second, issuers of e-money could, if they wished, transcend the jurisdiction of national legal tender laws, the compulsory use of central bank clearing accounts and other regulations by which the government controls the money supply.

At least initially, we can expect e-money to be denominated in national currencies, in order to ensure its ready acceptability and to obtain the approval and cooperation of the authorities. However, the demand for money to act as a stable store of value would see users of e-money seek out units denominated in national currencies with a very stable value. To the extent that national governments fail to provide this stable store of value by way of their own currencies, people can be expected to turn to e-money denominated in the currencies of other governments or even private issuers of currency backed by valuable assets or industrially useful commodities. Already, the National Westminster Bank-sponsored Mondex card allows users to store value denominated in up to five different currencies (Stuber, 1996:13). Gold-backed c-money is also currently available on the Internet, although its limited acceptability has prevented it from being widely used. 
The implications of these developments are far reaching. Central banks face the prospect of losing control over a significant proportion of the domestic money supply to the extent that people come to use money that is not backed by its own liabilities. While this may sound disturbing, it should not be. The theory of free banking tells us that a regime of competing, privately-issued currencies can result in a self-regulating monetary system that would represent a considerable improvement on the centralised monetary system under which we currently operate.

The principal problem with the central bank's control over the supply of money is not simply that this power can be abused (although historically this has often been the case). The more serious problem is that, even if the central bank is well intentioned, it cannot reliably anticipate the public's future demand to hold money. It has to make a more-or-less educated guess, just as a central planner has to guess at the likely future demand for any other good or service. When the central bank gets it wrong and produces an excess supply or demand for money, the economy as a wholc has to adjust to the monetary disequilibrium so created. This is because money lacks a price of its own, so any excess demand or supply must be cleared through changes in the relative prices of other goods and services, inflating or deflating the monopoly currency in the process. The real side of the economy is, thus, needlessly distorted by the nominal side.

This is why the debate over central bank independence is somewhat beside the point. Central bank independence seeks to ensure that central bankers have the right incentives to pursue a monetary policy aimed at monetary stability. It does this by insulating the central bank from inappropriate political pressures in its conduct of monetary policy. There are practical limitations to this process (Kirchner, 1995). But even if a central bank has the right incentives to pursue a form of monetary stability, it faces some fundamental problems in its attempts to equate money supply and demand. As Sechrest (1993:73) points out, the principal problems facing central banks in promoting monetary equilibrium are not procedural or political, but epistemological. Central banking institutions are unable to come to terms with the 'knowledge problem' identified by Hayek: information that is dispersed in the market place (such as that concerning the demand for money) can be revealed and coordinated only by market mechanisms. While greater independence for central banks might help ensure that central bankers are better motivated in their regulation of the money supply, it cannot address this more fundamental epistemological problem facing a central monetary authority.

Under free banking, by contrast, the banking system works automatically to ensure that the supply of money equals the demand to hold cash balances (see Selgin, 1988). Thus the banking system, rather than the economy as a whole, adjusts to any monetary disturbance. The level of economic activity is no longer vulnerable to the all too fallible judgements of politicians and central bankers in their conduct of monetary policy. A system of free banking would thus have avoided the 1990-92 recession, which is widely acknowledged to have been caused by an overly restrictive monetary policy on the part of the Reserve Bank. Australia is not alone in this regard. The failure of the relatively independent US Federal Reserve to offset a sig- 
nificant deceleration in monetary growth was a major cause of the US recession in 1990-91 (Buchanan \& Fand, 1993).

The use of e-money has significant implications also for fiscal policy. As Harper and Leslie (1995) have pointed out, the progressive elimination of hand-tohand currency by stored-value cards will result in the erosion of the seigniorage revenue that the Reserve Bank passes on to the Treasury. . The security and privacy features of e-money also have significant implications for the government's power to tax. The authorities will increasingly be unable to monitor financial transactions for the purposes of tax collection and compliance. Currency competition will work to eliminate inflation and the inflation tax. The authorities thus face significant losses in some of their traditional sources of revenue, which could prompt a search for new ways of raising funds.

Concerns have been expressed by the law-enforcement community that emoney will increasingly be used for the purposes of money laundering and other criminal activity, and have called on its use to be regulated accordingly. However, this assumes that one of the functions of a monetary and payments system is to assist in law enforcement. Money laundering and other illicit financial transactions are symptomatic of other criminal activity, which should be attacked at its source. For example, much organised criminal activity could be stopped through the multilateral decriminalisation of the use and supply of narcotics. Unfortunately, there is more public revenue to be obtained in chasing the proceeds of crime than in eliminating the (largely victimless) crimes that generate those proceeds in the first place.

\section{Implications for Prudential Supervision}

E-money has similar implications for prudential supervision of financial systems. Existing regulatory frameworks are already struggling with the fact that 'modern financial systems defy effective regulation' (Benston \& Kaufman, 1996:695). This regulatory task will become even more difficult as the Internet permits financial institutions to transcend national boundaries. While some find this prospect disturbing, the theory and history of free banking suggests that it need not be. The weight of evidence argues that financial institutions function more efficiently and with less risk in the absence of government regulations. Whatever prudential supervision is demanded by the public can be provided by the private sector (see, for example, Benston \& Kaufman, 1996; Dowd, 1996).

\section{Regulatory Responses}

What can the authorities do about these developments? Not much, it seems, at least not without massively re-regulating financial, computer and telecommunications systems. This is not a realistic possibility. A more rational response would be for the authorities to acquiesce in, if not facilitate, these developments, which will require a new and uncharacteristic humility on the part of those who have grown accustomed to exercising power over the rest of us. 
One possible response would be for the government to freeze the existing stock of fiat money and allow freedom of entry into currency issue and the provision of payment and settlement services, which could then be denominated in the existing stock of frozen base money or some other asset. Even critics of free banking have conceded that such freedom of entry is essentially unobjectionable (for example, Meltzer, 1987:217). This would secure the benefits of free banking in terms of promoting monetary stability and eliminating the effects of monetary disturbances on the real side of the economy, while eliminating many of the transitional uncertainties that may otherwise accompany a move towards a more competitive monetary system.

However, there is little sign that governments are willing to face up to the implications of these developments. For example, a recent Bank of Canada technical report on e-money concluded that 'gradual shifts in the demand for currency arising from such innovations as the electronic purse could be offset by the Bank of Canada through its control over the supply of settlement balances held by the direct clearers in the Canadian Payments Association' (Stuber, 1996:30). But this assumes that the issuers of e-money won't seek to bypass the central bank-sponsored settlements system altogether. The prospect that European Monetary Union will be delayed beyond 1999 raises the possibility that e-money will beat the new European currency into circuiation. In that event, 'e-money may make the whole EMU project an obscure anachronism' (Keating, 1995:15).

Despite some prominent calls to take up these issues (for example, Turnbull, 1996:13), there is so far little sign that the new inquiry into Australia's financial system will consider some of the more far-reaching implications of e-moncy. The danger here is that the authorities will either intentionally or inadvertently stifle our ability to make the best use of emerging technologies.

\section{Conclusion}

The advent of e-money and associated payments systems has the potential to bring about significant change in the financial sector. It also has significant implications for the monetary system and its relationship to the wider economy. The widespread use of competing, privately-issued electronic money will result in a more appropriate nominal framework for the real economy, free of the honest and notso-honest mistakes of central bankers and politicians in their conduct of monetary policy. Perhaps the most revolutionary implications of e-money, however, are those for national governments. Governments' finances and influence over the economy have long rested on two central pillars: the power to tax and the power to create money. Privately issued e-money undermines these two central pillars of government. The likely result is a significant reduction in the size and power of the state. 


\section{References}

Benston, G. \& G. Kaufman (1996), 'The Appropriate Role of Bank Regulation', The Economic Journal 106: 688-97.

Buchanan, J. \& D. Fand (1993), 'Monetary Malpractice: Intent, Impotence or Incompetence?', Critical Review 6(4): 457-69.

Chaum, D. (1995), Testimony Before US House of Representatives Committee on Banking and Financial Services, Subcommittee on Domestic and International Monetary Policy, 25 July. (http://www.digicash.com).

Dowd, K. (1996), 'The Case for Financial Laissez-faire,' The Economic Journal 106: 679-87.

Harper, I. \& P. Leslie (1995), 'Electronic Payments Systems and their Economic Implications', Policy 11(1): 23-8.

Holland, K. \& A. Cortese (1995), 'The Future of Money: E-Cash Could Transform the World's Financial Life', Business Week, 12 June: 36-46.

Keating, G. (1995), 'Electronic Money in a Race with EMU', Financial Times, 2 November.

Kirchner, S. (1995), 'Central Bank Independence and Accountability: The New Zealand Case', Agenda 2(2): 169-80.

Meltzer, A. (1987), 'Monetary Reform in an Uncertain Environment', in J. Dorn \& A. Schwartz (eds), The Search for Stable Money: Essays on Monetary Reform, University of Chicago Press, Chicago.

North, D. (1990), Institutions, Institutional Change and Economic Performance, Cambridge University Press, Cambridge.

Sechrest, L. (1993), Free Banking: Theory, History and a Laissez-Faire Model, Quorum Books, Westport, Conn.

Selgin, G. (1988), The Theory of Free Banking: Money Supply under Competitive Note Issue, Rowman \& Littlefield, Totowa.

Stuber, G. (1996), The Electronic Purse: An Ovenview of Recent Developments and Policy Issues, Bank of Canada, Ottawa (Technical Report No. 74).

Turnbull, S. (1996), 'Digital Cash Isn't Funny Money', The Australian Financial Review, 1 April. 